УДК 338.46

DOI: $10.15673 /$ fie.v11i3.1465

\author{
Дишкантюк О.В. \\ кандидат технічних наук, доцент \\ кафедра готельно-ресторанного бізнесу \\ Одеська національна академія харчових технологій \\ вул. Канатна, 112, м. Одеса, Україна, 65039 \\ E-mail: dyshkantyuk@ukr.net \\ ORCID ID: 0000-0001-9812-1916
}

\title{
СИСТЕМА ПОСЛУГ “АLL INCLUSIVE” В АСПЕКТІ ЕКОНОМІКИ ВРАЖЕНЬ ТА ПЕРСПЕКТИВИ ІІЇ ВПРОВАДЖЕННЯ В УКРАЇНІ
}

У роботі здійснений аналіз системи послуг "Все включене" в аспекті економіки вражень. На думку автора, економічна сутність системи "Все включено" полягає в тому, що це комплекс товарів та послуг, які необхідні для формування вражень споживачів. Враження, які отримують гості на різних етапах свого відпочинку, володіють корисністю, споживчою цінністю та в кінцевому підсумку мають вартість. Вона створюється в процесі взаємодії з постачальниками різних послуг, кожен з яких робить свій внесок в створення цілісного враження і тим самим формує вартість кінцевого продукту гостинності. Технологічна послідовність вражень формує ланцюги доданої вартості. I ці ланцюги об'єднують суб'єктів гостинності, як в межах одного, так і різних інфрраструктурних секторів.

Визначені сильні та слабкі сторони системи "Все включене", проаналізовані загрози та можливості впровадження даної системи в Україні. Охарактеризовані особливості проектування транспортних послуг, розміщення, харчування та анімацій системи "Все включене" в аспекті формування чотирьох областей вражень - розваги, навчання, відхід від реальності, естетика. Зроблено висновок щодо можливості та доцільності впровадження формули "Все включене" в умовах України, що дозволяє розвивати внутрішній туризм, утримуючи туриста всередині країни, надаючи йому все те, що він раніше отримував за кордоном, а також залучити іноземних туристів, насамперед з ближнього зарубіжжя. Приведені рекомендації щодо забезпечення конкурентоздатності формули "Все включене" в умовах України. Означені напрями подальших досліджень, які полягають у необхідності проведення сегментування гостей, вивчення їх ментальних особливостей, потреб, настроїв, інтересів.

Ключові слова: економіка вражень, гостинність, кінцеві та проміжні послуги, продукт гостинності, "Все включене".

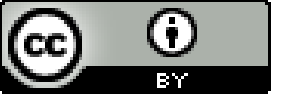

This work is licensed under a Creative Commons Attribution 4.0 International License http://creativecommons.org/licenses/by/4.0/
Постановка проблеми та її зв'язок з важливими науковими та практичними завданнями. В сучасній ринковій економіці важливу роль відіграє сфера гостинності. Гостинність вже набула характерних рис індустрії і $є$ багатоплановою та багатофункціональною сферою суспільного виробництва. Основним трендом економічного розвитку $\epsilon$ перехід до нового мислення та сприйняття сучасного етапу суспільних відносин, в якому пріоритети для споживачів полягають не стільки у товарах та послугах, скільки у враженнях, які вони від цього отримують [1]. Розвиток індустрії гостинності в Україні потребує комплексного вирішення проблем ринку послуг та вражень, який почав приближатися до світових стандартів. Україна має потужний курортно-рекреаційний потенціал, ефективне освоєння якого може стати вагомим внеском в розвиток національної економіки.

Аналіз останніх публікацій по проблемі. Наукова проблема досліджень економічної, сервісновиробничої, організаційно-управлінської, проектної діяльності у сфері послуг висвітлена у працях таких вчених, як Дж.Уокер, Р. Браймер, Дж. Х. Гілмор, Дж.Б. Пайн., Ф. Котлер, В. Мидлтон, 3. К. Караджова, С. Байлик [2-8]. Дослідження щодо комплексного функціонування індустрії гостинності як системи направленої на створення комфортних умов відвідування нових місць у справі чи для відпочинку, знаходження нових вражень фактично мало вивчено. Публікації з теми статті нечисленні. Досвід готелів Туреччини в розвитку системи "Все включене" та напрями впровадження цієї системи в логістичному аспекті вивчав І. Смірнов [9]. Автором проаналізовано логістичні особливості системи "Все включене", зокрема узгодження обсягів закупівель сировини та готових виробів з обсягом та структурою туристичних потоків. 3. К. Караджова досліджувала аспекти впровадження цієї системи в Болгарії [7]. Але на сьогоднішній час відсутні праці з дослідження системи "Все включене" в аспекті економіки вражень та застосування цієї системи в Україні.

Формулювання цілей дослідження. Метою дослідження є комплексний аналіз системи "Все 
включене” („All Inclusive”) в сфері гостинності в аспекті економіки вражень та визначення перспектив застосування даної системи в Україні. Для досягнення мети були поставлені наступні задачі: визначити сильні та слабкі сторони системи "Все включене", проаналізувати загрози та можливості в умовах системи, а також напрями впровадження даної системи в Україні

Виклад основних результатів та їх обгрунтування. Система "Все включене" є багатогранною концепцією відпочинку, яка полягає в наданні комплексу послуг: транспортні послуги, розміщення, харчування, анімаційні та інші послуги. Зародження системи "Все включене" деякі автори пов'язують 3 туризмом в Африці, за даними інших авторів, вона сходить до 50-х років XX століття і пов'язана з фран- цузькою мережею “Club Mediterranian” (або Club Med). У 1960-х роках система „Все включене” з успіхом застосувалась на круїзних океанських лайнерах. У 1970-х близько берегів Куби з'явився цілий острів „All Inclusive”- Кайо-Ларго. Одним з перших готелів 3 повноцінною системою „Все включене” став „Negril Beach” на Ямайці, відкритий в 1976 році (нинішня назва готелю - „Hedonism II”). Пізніше, ідея була прийнята іншими компаніями і швидко розвивається в Западній Свропі, США і Канаді. В кінці 1980-х років систему „All Inclusive” почала масово впроваджувати в свій туристичний бізнес Туреччина. За даними, приведеними І. Г. Смирновим [9] в Туреччині за цією системою працюють 86 \% готелів, в Домініканській республіці - 95 \%, Таїланді та Китаї - 70 \%, Сгипті - 35 \%, Тунісі та Кіпрі - 20 \% тощо (табл. 1).

Таблиця 1

Країни - рекордсмени системи „Все включене” (за відсотком готелів, що працюють за цією системою) [9]

\begin{tabular}{|l|c|}
\hline \multicolumn{1}{|c|}{ Країна } & $\begin{array}{c}\text { Відсоток готелів, що працюють за системою } \\
\text { „Все включене” }\end{array}$ \\
\hline Домініканська республіка & 95 \\
\hline Країни Карибського басейну & 90 \\
\hline Туреччина & 86 \\
\hline Таїланд & 70 \\
\hline Китай & 70 \\
\hline Мальдівська республіка & 50 \\
\hline Сгипет & 35 \\
\hline Кіпр & 20 \\
\hline Туніс & 20 \\
\hline
\end{tabular}

До числа нових країн, що починають застосовувати систему „Все включене”, нині додалася Чорногорія, Болгарія, Хорватія, Фінляндія.

На сьогодні у світовій практиці є декілька варіантів системи "Все включено"

MAX. INCLUSIVE включає проживання в ізольованому (приватному) курорті або курорті вищої категорії екзотичного відокремленого місця, поєднуючи унікальну природу 3 відмінною туристичною інфраструктурою. Пропозиція включає в себе: транспорт (повітряний, морський, наземний) і трансфер до засобу розміщення (курорт, готельно-ресторанний комплекс); розміщення в сімейних віллах або бунгало серед екзотичної природи; харчування в розкішних ресторанах $з$ різноманітною кухнею і в основному 3 меню "A La Carte". Відмінна особливість даної системи в тому, що в вартість туру включені абсолютно всі напої, в тому числі алкоголь іноземного виробництва і тютюнові вироби (сигарети, сигари і сигарили). Безалкогольні напої та пиво в міні-барі номера включаються в пакет. Крім цього, не існує обмеження і за часом - гості мають можливість замовити будьякі напої на території готелю цілодобово. Дана система гарантує гостям широкий спектр додаткових послуг: навчання та інструктаж з різних видів спорту (гольф, плавання, серфінг, дайвінг і т.д.).

Система IMPERIAL передбачає включення у вартість туру всіх алкогольних і безалкогольних на- поїв, в тому числі і іноземного виробництва. Також максимально розширено кількість поданих страв в ресторанах і барах готелю. Крім цього, готель пропонує гостям спеціалізовані ресторани (наприклад, рибні, італійські і т.д.), де необхідно буде бронювати столик заздалегідь. У сфері безкоштовних розваг так само $є$ додаткові плюси - аж до деяких моторних видів спорту (водні лижі, банан).

У системі ULTRA ALL INCLUSIVE в вартість туру включені не тільки місцеві, а й імпортні напої, як алкогольні, так і безалкогольні. Шведський стіл ресторанів готелю так само пропонує гостям широкий вибір страв.

Такі види сервісу як FULL BOARD PLUS (FB +) $i$ HALF BOARD PLUS (HB +) гарантують включення в вартість туру місцевого пива і вина на «шведському столі». На відміну від системи All inclusive не гарантують надання інших безкоштовних видів послуг.

Окрім того вирізняють «змішаний» $\mathrm{i}$ «плаваючий» сервіси All inclusive:

Зміманий сервіс означає, що на території конкретного готелю обслуговування туристів здійснюється як за системою All inclusive, так і за іншими системами (BВ, НВ, FB). Вибір системи обслуговування залежить від побажання самих туристів. Задля уникнення плутанини гостям готелю пропонується скористатися індивідуальною готельною системою 
відмінності. Як правило, це або спеціальні браслети, або інші атрибути, за якими персонал готелю безпомилково зможе визначити обрану гостем систему обслуговування.

Плаваючий сервіс полягає в тому, що деякі готелі в залежності від сезонності пропонують своїм гостям обслуговування за різними категоріями. Наприклад, в літній період готель працює за системою All inclusive, а в зимовий період по системі НВ.

Як зазначає у своєму дослідженні 3. К. Караджова, філософією системи "Все включено" - $\epsilon$ пропозиція якісних послуг від дверей до дверей, найкраща програма для додаткових послуг i додаткових пільг з найкращим співвідношенням ціни, сервісу i високої якості основних і додаткових послуг [7]. В центрі системи знаходиться гість - а туроператор, власники готелів та ввесь обслуговуючий персонал беруть на себе функції господаря у відношенні до гостей. Зусилля гостинних господарів направляються з однісї сторони на всебічне задоволення потреб гостей, з іншої - на забезпечення вражень, що особливо актуально в епоху переходу до економіки вражень. Основним трендом економічного розвитку є перехід до нового мислення та сприйняття сучасного етапу суспільних відносин, в якому пріоритети для споживачів полягають не стільки у товарах та послугах, скільки у враженнях, які вони від цього отримують На сучасному етапі розвитку продуктивних сил послуги звичайного обслуговування автоматизовано i вони сприймаються як стандартний процес, а людей більше цікавлять послуги, від яких вони отримують задоволення та враження. У випадку, коли послуги звичайного обслуговування не відповідають стандарту (по якості та кількості), то враження від них та від гостинності буде низьким. На нашу думку, враження складаються зі звичайного комплексу послуг (першого рівня) та зі специфічного обслуговування (другого рівня)[10]. Гостинність - це враження, які одержують люди від послуг першого та другого рівнів, які поділяються на проміжні та кінцеві, які формують продукт гостинності. Послуги другого або кінцевого рівня справляють на людей яскраві враження від гостинності, тому що за цими послугами люди їдуть на тимчасове або постійне перебування і ці послуги включають комплекс послуг інфраструктурних секторів гостинності. На нашу думку, продукт гостинності це комплексний, сукупний набір послуг, зв'язаних між собою логістичним ланцюгом, що об'єднує певний набір проміжних послуг різних інфраструктурних секторів (або в межах сектору) в результаті якого одержують продукт гостинності. Чим більш довгий логістичний ланцюг одержання кінцевого продукту гостинності, тим більше налічується послуг, які є кінцевими у одних логістичних ланцюгах, стають проміжними у інших [10]. Так, наприклад, коли гість приїздить на відпочинок в готельно-ресторанний комплекс за системою All inclusive, то гостинність цього місця буде визначатись комплексом послуг проміжного рівня, що формують кінцевий продукт гостинності. Враження, які отримують гості на різних етапах свого відпочинку, володіють корисністю, спо- живчою цінністю та в кінцевому підсумку мають вартість. Вона створюється в процесі взаємодії з постачальниками різних послуг, кожен $з$ яких робить свій внесок в створення цілісного враження і тим самим формує вартість кінцевого продукту гостинності. Технологічна послідовність вражень формує ланцюги доданої вартості. І ці ланцюги об'єднують суб'єктів гостинності як в межах одного сектору, так різних інфраструктурних секторів.

Компанії, що працюють в секторі готельноресторанного бізнесу і усвідомлюють сучасні тенденції економіки, пропонують гостям не просто товари і послуги, а враження, які викликають у гостей широку гаму емоцій. Як справедливо зазначають Джозеф Б. Пайн та Джеймс Х.Гілмор, усі попередні економічні пропозиції - сировина, товари, послуги - не проникали у внутрішній світ покупця, в той час як враження по своїй суті є особистістними. Вони торкаються людини на емоційному, фізичному і навіть духовному рівнях [4]. Для того, щоб витримати конкурентну боротьбу, компанії гостинності повинні навчитися створювати для своїх гостей захоплюючі враження. В індустрії гостинності $є$ можливість застосування усіх чотирьох областей вражень - розваги, навчання, відхід від реальності, естетика .

Розглянемо послуги другого рівня від ступеню вражень, які отримують гості на прикладі системи “All inclusive”, яка передбачає комплекс послуг - транспортні послуги, розміщення, харчування, анімаційні та інші послуги. При наданні транспортних послуг важливий вибір компанії, які орієнтуються на економіку вражень. Як описують Джозеф Б. Пайн та Джеймс Х.Гілмор, авіакомпанія British Airways пропонує здебільшого естетичні враження: персонал піклується про гостей так, що їм нічого не потрібно робити, тільки приймати цю турботу. За словами Роберта Ейлінга, наступника Коліна Маршалла на посаді головного фінансового директора, компанія зараз працює над впровадженням певних розважальних елементів в загальне враження від польоту і приведення їх у відповідність із загальною естетичною концепцією. Він переконаний, що фільми частіше будуть дивитися в літаках, а не в кіно. «Люди все більше думатимуть про авіакомпанії не тільки як про транспортні, а й як про розважальні системи, - говорить він» [4].

В рамках системи All inclusive комплекс послуг та власні стандарти обслуговування розробляються в залежності від категорії номеру та умов, які завчасно оговорюються. Велика увага приділяється організації харчування гостей, зокрема пропонуються варіанти для задоволення різноманітних бажань. Ресторанний комплекс, як правило, проектується 3 закладів різних типів - ресторани, які працюють за системою “шведський стіл”, ресторани “A la carte”, кавярні, снек-бари, лоббі-бари, лаундж-бари, пляжні бари, пул-бари, дитячі ресторани. У сучасних комплексах 5 зірок відмічається тенденція відходу від системи “шведський стіл”, а пропонується система “А ля карт” з обслуговуванням офіціантами. При цьому 
на території одного комплексу функціонують декілька різних спеціалізованих, як правило, за національною кухнею ресторанів. Гість попередньо бронює той чи інший ресторан. Ця послуга $є$ безкоштовною для гостя, хоча паралельно можуть функціонувати і ресторани за окрему плату. Так наприклад, готельноресторанний комплекс LUJO (Бодрум, Туреччина) пропонує гостям 9 спеціалізованих ресторанів.

Таблиця 2

Спеціалізована гастрономія готельно-ресторанного комплексу LUJO (Бодрум, Туреччина)*

\begin{tabular}{|l|l|}
\hline Ресторан & спеціалізація \\
\hline Koza & страви різних країн світу \\
\hline SHIBORI & $\begin{array}{l}\text { страви азіатської кухні на будь-який смак, ТЕРPANYAКI, японсь- } \\
\text { кий гріль Робата та суші-бар }\end{array}$ \\
\hline SORRISO & $\begin{array}{l}\text { страви італійської кухні з різноманітним меню з домашньої пасти, } \\
\text { різотто та морепродуктів }\end{array}$ \\
\hline EL GAUCHO & стейки з гімалайською сіллю \\
\hline ALARGA & ресторан морепродуктів \\
\hline ASMA & ресторан регіональної турецької кухні \\
\hline Quinoa & ресторан мексиканської кухні \\
\hline Oра! & ресторан середземноморської кухні \\
\hline Sесrеt & ресторан інтернаціональної кухні в приватній зоні \\
\hline *авторська розробка &
\end{tabular}

Сніданки та обіди в ресторанах організовані за загальним меню, а ввечері ресторани перевтілюються в спеціалізовані ресторани. Вибір гостя ресторану на вечерю попередньо узгоджується. Обслуговування відбувається не за системою “шведський стіл”, а за системою “A la carte”, що на наш погляд більш доцільно, так як серед інших переваг дозволяє уникнути черг та скупчення гостей, що часто дратує гостей. В ресторанах гості отримують не тільки задоволення потреби у їжі - а й враження. Гості отримують гастрономічні задоволення від страв етнічних кухонь, що дозволяє глибше пізнати культуру, адже національна кухня є культурною спадщиною кожного народу. А в економіці вражень в конкуренцію включаються національні культури. Як справедливо відзначає академік Ю. Пахомов, в конкурентну боротьбу все більше втягуються не тільки економічні фактори, а й "цінністні складові поведінки, властивої одній країні, чи цивілізації в цілому”. В умовах глобальної відкритості “ визрівають висновки про цінності культури, як про вирішальні фактори міжнародної конкурентоспроможності [11].

Відкрита кухня ресторану дозволяе гостю поглинати враження в процесі спостереження за процесом приготування їжі та навіть стати активним учасником цього процесу. Так, приготування страв кухарем безпосередньо перед столиком гостя у турецькому ресторані Asma з застосуванням фламбування не залишає жодного з гостей байдужим. Цікавим $\epsilon$ досвід азіатського ресторану теппаньякі, де організують шоу, своєрідний кулінарний театр, у якому всі страви шеф-кухар готує на очах у гостей. Театралізоване дійство в ресторані - перетворення послуги харчування в театральну постановку, в якій є сценарій i виконавці персонал, а також і сам споживач, залучений в дійство. Театралізація включає: наявність сценарію (головної теми), створення позитивних емоцій, відсутність негативних емоцій, пропозиція страв як символів цінності спогадів, включення всіх п'яти ор- ганів почуттів. У ресторані розгортається дійство, що перетворює гостей зі спостерігачів на повноправних учасників.

Головним елементом системи анімацій є людина (гість). Анімації слугують задоволенню емоційних, фізичних і навіть духовних потреб. Тому при проектуванні анімацій необхідно провести сегментування гостей, вивчити ментальні особливості, потреби, настрої, інтереси. Без знання психологічних особливостей гостей неможливо розраховувати на досягнення бажаного результату і на високу ефективність інтелектуального та емоційного впливу на аудиторію. Провівши попередні дослідження можливо приступати до розробки анімаційних програм в системі "Все включено", плануючи різноманітні заходи в комплексі та на пляжі, зокрема, дискотеки, концертні програми, перегляд фільмів на пляжі, настільний теніс, дартс, аеробіка, пілатес, йога, сауна, хамам, танці, аквааеробіка, міні-футбол, пляжний волейбол, водні лижі, дайвінг, верхова їзда, поло та інші ігри, та розраховуючи при цьому на ефективність.

Переваги для гостей в системі обслуговування "All Inclusive" можна звести до наступного:

- "економія" - вартість подорожі до готелю за системою "Все включено" обходиться дешевше, аніж такі ж послуги в готелі аналогічного класу який не надає послуги з організації подорожі, харчування та розваг;

- гості можуть більш чітко спланувати свої витрати, так як все прораховується і оплачується наперед;

- гості позбавляються від необхідності витрачати свій емоційний ресурс “турбуватися” про харчування та програму перебування, так як ця проблема вирішена;

- безкоштовна участь у виборі різних заходів на території готелю і закладах харчування і розваг в залежності від віку та інтересів;

- широкий вибір анімацій для дітей є перева- 
гою для сімейних пар $з$ дітьми;

- є можливість брати участь в приготуванні специфічних для країни і регіону страв, під особистим керівництвом шеф-кухаря;

- можливість в короткий термін відвідати різні концептуальні ресторани без додаткової оплати;

- безпека. Готелі, які працюють за системою "All Inclusive" мають охорону та пропускну систему та сприймаються гостями як безпечні.

Переваги для власників в системі обслуговування "All Inclusiv":

- раціональне використання матеріальнотехнічної бази комплексу;

- ефективне планування, зокрема в організації постачання, планування завантаження готелю;

- ефективне використання інформаційних технологій для планування і контролю усіх процесів;

- спеціалізація персоналу та його ефективна структуризація;

- висока якість обслуговування;

- здешевлення собівартості сировини за рахунок великих обсягів;

- більш повноцінне використання продуктів харчування;

- залучення додаткового сегменту гостей 3 обмеженими фінансовими можливостями, які за інших умов не можуть дозволити собі скористатися послугами готелю.

Серед недоліків системи "All Inclusive" насамперед потрібно означити наступне:

- досить часто очікування гостей не співпадають 3 реальністю. Це насамперед відноситься до організації харчування, так як можливість різноманітного харчування обмежується низьким бюджетом;

- свобода вибору харчування та розваг гостями окреслена межами готельно-ресторанного комплексу;

- так як продукти харчування та напої, які пропонуються в комплексі є безкоштовними, значна частина гостей перевищує норми споживання страв та напоїв, що негативно відображається на здоров'ї та $€$ причиною конфліктних ситуацій;

- при змішаній системі "All Inclusive" в готелі можуть розміщатися гості, які не оплатили додаткові послуги і не можуть споживати напої. Це надає певний дискомфорт. В той же час власники повідомляють про випадки, коли гостей, які не заплатили за певні послуги, пригощають чи продають їм напої;

- низька мотивація працівників готелю, внаслідок того, що більшість гостей не платять “чайові”;

- некваліфіковані кадри, що пов'язано з сезонністю роботи та економічними факторами;

- досить обмежена частина туристів відвідує місцеві ресторани поза межами комплексу, що негативно відображається на місцевому бізнесі.

Саме через останню причину деякі готелі Туреччини та Єгипту починають відмовлятися від системи „Все включене”, але роблять це поступово. За думкою керівника федерації готелів Туреччини О. Аіка, для готелів є доцільним пропонувати одразу декілька пакетів: від найпростіших і відповідно найдешевших (приміром, тільки харчування) до повновагомого „Все включене”. При цьому різні категоpiї гостей можна відрізняти за допомогою різнокольорових браслетів, про які згадувалося вище [9].

Досліджуючи можливості системи "Все включене" З.К. Караджова [7] звертає увагу на те, що країни, які мають “Все включене” залучають близько 170 млн туристів в рік. В Україні допоки що система "Все включене" не знайшла широкого розповсюдження, але на наш погляд є достатні передумови та перспективи іiі впровадження для певного сегменту готельно-ресторанних комплексів. Особливо це актуально для морських курортів Півдня країни. Адже таким чином можливо втримати туриста всередині країни, надаючи йому все те, що він раніше отримував за кордоном, а також залучити іноземних туристів, насамперед з ближнього зарубіжжя. Враховуючи економічну ситуацію в України та низькі доходи населення, а відтак і низьку платоспроможність, впровадження системи "Все включене" з однієї сторони, надасть можливість людям 3 достатньо низьким рівнем доходів отримати можливість відпочити в достатньо комфортних умовах, з іншої сторони це забезпечує більш високе завантаження готелів, а відповідно зайнятість населення. Саме ця формула сприяла швидкому збільшенню числа західних туристів з обмеженими фінансовими можливостями у Туреччині, Болгарії, Єгипті. Свої наміри щодо впровадження цієї системи в Україні задекларувала управляюча компанія Ribas Hotels Group, яка сьогодні має позитивний досвід впровадження «Все включене»в готелі White House на узбережжі Чорного моря, у смт. Коблево (Миколаївська обл.). Генеральний директор управляючої компании Ribas Hotels Group Артур Лупашко, аналізуючи досвід впровадження такого нововведення підкреслив, що результатом став приріст серед гостей готелю на $30 \%$.

Висновки та перспективи подальших досліджень. У роботі здійснений аналіз системи послуг "Все включене" в аспекті економіки вражень. На наш погляд, економічна сутність системи "Все включено" полягає в тому, що це комплекс товарів та послуг, які необхідні для формування вражень споживачів. Враження, які отримують гості на різних етапах свого відпочинку, володіють корисністю, споживчою цінністю та в кінцевому підсумку мають вартість. Вона створюється в процесі взаємодії з постачальниками різних послуг, кожен 3 яких робить свій внесок в створення цілісного враження і тим самим формує вартість кінцевого продукту гостинності. Технологічна послідовність вражень формує ланцюги доданої вартості. I ці ланцюги об'єднують суб'єктів гостинності, як в межах одного сектору, так різних інфраструктурних секторів. Автором охарактеризовані особливості проектування транспортних послуг, розміщення, харчування та анімацій системи “Все включене” в аспекті формування чотирьох областей вражень - розваги, навчання, відхід від реальності, естетика, що може бути використано при впровадженні системи “All inclusive” суб'єктами готельно-ресторанного 
бізнесу. Результати проведеного дослідження дозволяють зробити висновок щодо можливості та доцільності впровадження формули "Все включене" в умовах Україниі сформулювати рекомендації щодо успішного впровадження формули на підприємствах гостинності та забезпечення їх конкурентоздатності:

- проектувати для гостей враження. В індустpiï гостинності є можливість застосування усіх чотирьох областей вражень - розваги, навчання, відхід від реальності, естетика;

- провести сегментування гостей, вивчити їх ментальні особливості, потреби, настрої, інтереси і взаємодіяти з ними на емоційному рівні;

- забезпечити оптимальне співвідношення “ціна- враження";

- прагнути до розширення кількості та різноманіття додаткових послуг без суттєвої зміни ціни базового пакета;

- забезпечити різноманітність харчування, вивчивши кулінарні уподобання цільової аудиторії та забезпечивши низький фудкост за рахунок використання місцевої сировини;

- стимулювати інновації в послугах, технологіях, маркетингу;

- забезпечити професійність та постійне підвищення кваліфікації кадрів;

- впроваджувати системи мотивації персоналу;

- постійно вивчати потреби ринку і тенденції в індустрії гостинності;

Серед проблемних питань на наш погляд є недостатня підтримка з боку держави, недостатня кваліфікація персоналу, а відтак низька якість сервісу, застаріла матеріально-технічна база готелів та проблема інвестування нововведень, відсутність досліджень щодо вподобань потенційних гостей. Ці проблеми автор визначає як напрям подальших досліджень.

\title{
Література
}

1. Дишкантюк О. Економіка вражень - сучасний етап розвитку суспільного виробництва // Економіка харчової промисловості. 2016. Т. 8, вип. 4. С. 3-9; doi:10.15673/fie.v8i4.453

2. Уокер Дж. Р. Введение в гостеприимство / Дж. Р. Уокер.; пер. с англ. В.Н.Егорова. М.: ЮНИТИ ДАНА, 2012. $735 \mathrm{c}$.

3. Браймер Р.А. Основы управления в индустрии гостеприимства. М.: Аспект Пресс, 1995. 382 с.

4. Гилмор Дж. Х., Пайн Дж.Б. Экономика впечатлений: работа это театр, а каждый бизнес- сцена. М.: Вильямс, 2005. 304 с.

5. Котлер Ф., Боуэн Дж., Мейкенз Дж. Маркетинг. Гостеприимство и туризм: учеб. для вузов / Котлер Ф., Боуэн Дж., Мейкенз Дж.; пер. с англ. под ред. Р. Б. Ноздревой. М.: ЮНИТИ, 1998. 787 с.

6. Мидлтон В. Менеджмент туризма. М.: Юнити, 2009. 536 с.

7. Караджова 3. К. За или против формулы "Все включено" и ее совершенствовании в Болгарской образовательной сфере //Перспективы Науки и Образования. 2015. № 3 (15). С. 170-176

8. Байлик С. И. Гостиничное хозяйство. Организация, управление, обслуживание. К.: Дакор. 2008. 288 c.

9. Смирнов І. Г. Турецький досвід із застосування системи гостинності "Все включене" в туризмі та можливості його використання в Україні (логістичний аспект) // Наукові записки / Вінницьк. держ. пед. університету ім. М. Коцюбинського. Сер. Географія. 2011. Вип. 23. С. 55-66.

10. Дишкантюк О.В. Формуванння інфраструктурного забезпечення сфери гостинності // Економіст. 2016. №7. С. 25-28.

11. Пахомов Ю.М. Система цінностей як фактор конкурентоспроможності країн у глобальному світі // Економіка ринкових відносин. 2008. №(1). С. 38-45.

Стаття надійшла 5.07.2019

Стаття прийнята до друку 19.07.2019

Доступно в мережі Internet 16.10.2019

\author{
Дышкантюк О.В \\ кандидат технических наук, доцент \\ кафедра отельно-ресторанного бизнеса \\ Одесская национальная академия пищевых технологий \\ ул. Канатная, 112, г. Одесса, Украина, 65039 \\ E-mail: dyshkantyuk@ukr.net \\ ORCID ID: 0000-0001-9812-1916
}

\section{СИСТЕМА УСЛУГ «ALL INCLUSIVE» В АСПЕКТЕ ЭКОНОМИКИ ВПЕЧАТЛЕНИЙ И ПЕРСПЕКТИВЫ ЕЕ ВНЕДРЕНИЯ В УКРАИНЕ}

В работе осуществлен анализ системы услуг «Все включено» в аспекте экономики впечатлений. По мнению автора, экономическая сущность системы «Все включено» заключается в том, что это 
комплекс товаров и услуг, которые необходимы для формирования впечатлений потребителей. Впечатления, которые получает гость на разных этапах своего отдыха, владеют полезностью, потребительской ценностью и в конечном итоге имеют стоимость. Она создается в процессе взаимодействия с поставщиками разных услуг, каждый из которых делает свой взнос в создание целостного впечатления и тем формирует стоимость конечного продукта гостеприимства. Технологическая последовательность впечатлений формирует цепи добавленной стоимости. И эти цепи объединяют субъекты гостеприимства, как в пределах одного, так и разных инфраструктурных секторов. Охарактеризованы особенности проектирования транспортных услуг, размещения, питания и анимаций системы «Все включено» в аспекте формирования четырех областей впечатлений - развлечения, учеба, отход от реальности, эстетика. Определены сильные и слабые стороны системы, проанализированы угрозы и возможности внедрения данной системы в Украине. Приведены рекомендации относительно обеспечения конкурентоспособности формулы «Все включено» в условиях Украины. В индустрии гостеприимства есть возможность применения всех четырех областей впечатлений, для проектирования которых необходимо провести сегментацию гостей, изучить их ментальные особенности, потребности, настроения, интересы, и взаимодействовать с ними на эмоциональном уровне. Необходимо обеспечить оптимальное соотношение «цена - впечатление» и стремиться к расширению количеству и многообразию дополнительных услуг без существенного изменения цены базового пакета, обеспечить разнообразие питания, изучив кулинарные вкусы целевой аудитории и обеспечив низкий фудкост за счет использования местного сырья. При этом следует обеспечить профессионализм и постоянное повышение квалификации кадров и внедрять системы мотивации персонала.

Ключевые слова: экономика впечатлений, гостеприимство, конечные и промежуточные услуги, продукт гостеприимства, «Все включено».

\author{
Dyshkantiuk 0. \\ Ph.D., Associate Professor \\ Department of Hotel and Restaurant Business \\ Odessa National Academy of Food Technologies \\ Kanatna str., 112, Odessa, Ukraine, 65039 \\ E-mail: dyshkantyuk@ukr.net \\ ORCID ID: 0000-0001-9812-1916
}

\title{
«ALL INCLUSIVE SYSTEM OF SERVICES» IN THE ASPECT OF EXPERIENCE ECONOMYAND PERSPECTIVES OF ITS IMPLEMENTATION IN UKRAINE
}

The article is devoted to the analysis of "All inclusive" system of services within the aspect of experience economy. The author argues that economic essence of "All inclusive" system is the set of goods and services that are needed to form consumers' impressions. The impressions a guest receives at the different stages of the vacation have utility, consumer's value and ultimately a cost. It is created in the process of interaction with suppliers of different services, each of which contributes to the creation of holistic experience and thus form the cost of end product of hospitality. Technological sequence of experiences forms chains of added value. The chains are brought together by subjects of hospitality, both within the one or different infrastructure sectors. The features of designing transportation, accommodation, nutrition and animation services of "All inclusive" within the aspect of four areas of experience - entertainment, educational, esthetic, and escapist have been characterized. Strong and weak sides of the system, threats, and opportunities of system deployment in Ukraine have been analyzed. Recommendations have been given regarding ensuring the competitiveness of "All inclusive" formula within Ukrainian conditions. The hospitality industry has an opportunity of application of all four areas of experience for designing of which segmentation of guests, study of their mental characteristics, needs, interests, moods should be conducted as well as interaction with them at the emotional level. It is necessary to provide the best value for "money-experience" and seek to expand the number and variety of supplementary services without significant change in cost of basic the package, to ensure dietary diversity, by examining culinary tastes of target auditory and to ensure low food-cost by using local raw material. At the same time, professionalism and constant professional development of personnel should be ensured and personnel motivation systems should be introduced.

Keywords: experience economy, hospitality, final and intermediate services, product of hospitality, „All Inclusive”.

\section{References}

1. Dyshkantiuk, O. (2016). Ekonomika vrazhen - suchasnyy̆ etap rozvytku suspilnoho vyrobnytstva. Ekonomika kharchovoï Promyslovosti, 8(16), 3-9. doi: 10.15673/fie.v8i4.453 
2. Uoker, Dzh. R. (2012). Vvedenie v gostepriimstvo . (V. N. Egorov, Trans.). Moscow: YuNITI - DANA.

3. Braĭmer R. A. (1995). Osnovy upravleniia v industrii gostepriimstva. Moscow: Aspekt Press.

4. Gilmor, Dzh. Kh., \& Paĭn, Dzh. B. (2005). Ekonomika vpechatleniı̌: rabota eto teatr, a kazhdyı̆ biznesstsena. Moscow: Viliams.

5. Kotler, F., Bouen, Dzh., \& Meikenz, Dzh. (1998). Marketing. Gostepriimstvo i turizm. (R. B. Nozdreva, Trans.). Moscow: IuNITI.

6. Midlton, V. (2009). Menedzhment turizma. Moscow: Iuniti.

7. Karadzhova, Z. K. (2015). Za ili protiv formuly "Vse vkliucheno" i ee sovershenstvovanii v Bolgarskō̌ obrazovatelnoŭ sfere. Perspektivy Nauki i Obrazovaniia, (3 (15), 170-176.

8. Bă̌lik S I. (2008). Gostinichnoe khoziaǔstvo. Organizatsiia, upravlenie, obsluzhivanie. Kyiv: Dakor.

9. Smyrnov, I. H. (2011). Turetskyi dosvid iz zastosuvannia systemy hostynnosti "Vse vkliuchene" v turyzmi ta mozhlyvosti yoho vykorystannia v Ukraini (lohistychnyi aspekt). Naukovi Zapysky, (23), 55-66.

10. Dyshkantiuk, O. V. (2016). Formuvannnia infrastrukturnoho zabezpechennia sfery hostynnosti. Ekonomist, (7), 25-28.

11. Pakhomov, Yu. M. (2008). Systema tsinnostey̆ yak faktor konkurentospromozhnosti kraïn u hlobalnomu sviti. Ekonomika Rynkovykh Vidnosyn, (1), 38-45.

Received 5 July 2019

Approved 19 July 2019

Цитування згідно ДСТУ 8302:2015

Available in Internet 16.10.2019

Дишкантюк О.В. Система послуг “All inclusive” в аспекті економіки вражень та перспективи ії впровадження в Україні // Економіка харчової промисловості. 2019. Т.11, вип. 3. С. 80-87. doi: 10.15673/fie.v11i3.1465

Cite as APA style citation

Dyshkantiuk, O. (2019). «All inclusive system of services» in the aspect of experience economy and perspectives of its implementation in Ukraine. Food Industry Economics, 11(3), 80-87. doi: 10.15673/fie.v11i3.1465 